Matematikai Közlemények

III. kötet, 2015

doi:10.20312/dim.2015.09

\title{
Diofantikus számhármasok a Lucas-Lehmer sorozatokban
}

\author{
Gueth Krisztián \\ NymE TTMK Matematika és Fizikai Intézet \\ guethk@gmail.com
}

\begin{abstract}
ÖSSZEFOGLALÓ. Dolgozatunkban egy rögzített negyedrendủ Lucas-Lehmer sorozatra megállapítjuk, hogy nem adható meg hozzá diofantikus számhármas. A másodrendű sorozatoknál alkalmazott módszerek itt is használhatók, mert a LucasLehmer sorozatok a másodrendủek számos tulajdonságát megöröklik.
\end{abstract}

ABSTRACT. In this paper, we state that there does not exist diophantine triple for a given Lucas-Lehmer sequence. The methods applied for binary sequences can be used here, too, because the Lucas-Lehmer sequences inherit many properties of the recurrences of order two.

\section{Bevezetés}

Diofantikus szám $n$-esen olyan $a_{1}<a_{2}<\cdots<a_{n}$ pozitív egész számokból álló halmazt értünk, melyekre $a_{i} a_{j}+1$ minden $i, j$-re négyzetszámot ad. A kérdést az ókorban racionális számokra tekintették, Diofantosz találta az első ilyen számnégyest: 1/16, 33/16, 17/4 és $105 / 16$.

A problémát négyzetszámok helyett egy adott lineáris rekurzív sorozat elemeire vizsgálták az $n=3$ esetben. Florian Luca és Szalay László [2] bebizonyították, hogy a Fibonacci sorozathoz nem adható meg diofantikus számhármas, azaz nincsenek olyan $0<$ $a<b<c$ egészek, hogy $a b+1=F_{x}, a c+1=F_{y}$ és $b c+1=F_{z}$ volna valamely $x, y$ és $z$ indexekre. Szintén az ő eredményük [3], hogy a Fibonacci-sorozat asszociáltjához, a Lucassorozathoz egyetlen ilyen hármas létezik: $a=1, b=2$ és $c=3$. A nevezett két szerzö, valamint Clemens Fuchs [1] megadtak egy szükséges és elégséges feltételt arra, hogy egy nem degenerált másodrendủ sorozathoz végtelen sok hármas létezzen.

\section{Probléma és megoldása}

Mi a problémát bizonyos fajta negyedrendű sorozatokra vizsgáljuk. A Lucas-Lehmer sorozaton olyan negyedrendü sorozatot értünk, melynek rekurziójában az n-edik tag csak az $(n-2)$-edik és az $(n-4)$-edik függvénye, és a kezdőelemekre is teszünk megszorításokat. Egész pontosan legyenek $G_{0}=0, G_{1}=1$, valamint $G_{2}$ és $G_{3}$ tetszőleges egész számok, továbbá $n \geq 4$ esetén $G_{n}=A G_{n-2}+B G_{n-4}$, ahol $A$ és $B$ adott egész együtthatók. 
Ezek közül is egy konkrét sorozattal foglalkozunk, az $A=4, B=-1$ választás esetén. A továbbiakban az $\left(L_{n}\right)$ sorozaton az $L_{0}=0, L_{1}=1, L_{2}=1, L_{3}=3$ kezdőelemekkel megadott $L_{n}=4 L_{n-2}-L_{n-4}$ sorozatot értjük. Az alábbi állítást bizonyítottuk.

Tétel. Nem léteznek olyan $0<a<b<c$ egész számok és $x, y, z$ nem-negatív egész indexek, hogy

teljesüljön.

$$
\begin{aligned}
& a b+1=L_{x} \\
& a c+1=L_{y} \\
& b c+1=L_{z}
\end{aligned}
$$

A bizonyítás, többek között, azon múlik, hogy $L_{n}-1$ mindig felbomlik az $\left(L_{n}\right)$ sorozat és asszociált $\left(M_{n}\right)$ sorozata megfelelö tagjainak szorzatára. Például

$$
L_{n}-1=L_{(n-1) / 2} M_{(n+1) / 2}, \quad \text { ha } n \equiv 1(\bmod 4) .
$$

\section{Irodalomjegyzék}

[1] C. Fuchs, F. Luca, L. Szalay., Diophantine triples with values in binary recurrences, Ann. Scuola Norm. Sup. Pisa. Cl. Sci. III, 5 (2008) 579-608.

[2] F. Luca, L. Szalay., Fibonacci Diophantine Triples, Glasnik Math., 43(63) (2008) 253-264. (doi: http://dx.doi.org/10.3336/gm.43.2.03)

[3] F. Luca, L. Szalay., Lucas Diophantine Triples, Integers, 9 (2009) 441-457. 